\title{
Thermal Stability and Mechanical Properties of Glassy and Amorphous Ni-Nb-Zr Alloys Produced by Rapid Solidification
}

\author{
Hisamichi Kimura $^{1}$, Akihisa Inoue ${ }^{1}$, Shin-ichi Yamaura $^{1}$, Kenichiro Sasamori ${ }^{1}$, \\ Motonori Nishida ${ }^{2}$, Yoichiro Shinpo ${ }^{2}$ and Hitoshi Okouchi \\ ${ }^{1}$ Institute for Materials Research, Tohoku University, Sendai 980-8577, Japan \\ ${ }^{2}$ Fukuda Metal Foil \& Powder Co., LTD, Kyoto 607-8305, Japan
}

Rapidly solidified $\mathrm{Ni}-\mathrm{Nb}-\mathrm{Zr}$ alloys in a ribbon form with a thickness of about $20 \mu \mathrm{m}$ were prepared by a single roller melt-spinning technique. Amorphous alloys were formed in the composition range of 20 to 75 at $\% \mathrm{Ni}, 0$ to 60 at $\% \mathrm{Nb}$ and 0 to 80 at $\% \mathrm{Zr}$. Furthermore, glassy alloys were also synthesized in the range of 50 to 70 at $\% \mathrm{Ni}, 5$ to $35 \mathrm{at} \% \mathrm{Nb}$ and 5 to 45 at $\% \mathrm{Zr}$. The maximum temperature interval of the supercooled liquid region was $51 \mathrm{~K}$ for $\mathrm{Ni}_{60} \mathrm{Nb}_{20} \mathrm{Zr}_{20}$ alloy. The tensile fracture strength and Vickers hardness of the glassy $\mathrm{Ni}_{60} \mathrm{Nb}_{20} \mathrm{Zr}_{20}$ alloy are $2160 \mathrm{MPa}$ and 700 , respectively. Wide ribbons with a width of $50 \mathrm{~mm}$ of amorphous $\mathrm{Ni}_{42} \mathrm{Nb}_{28} \mathrm{Zr}_{30}$ and glassy $\mathrm{Ni}_{60} \mathrm{Nb}_{20} \mathrm{Zr}_{20}$ alloys were produced at a circumferential velocity of the copper roller of $20 \mathrm{~m} / \mathrm{s}$.

(Received February 20, 2003; Accepted April 17, 2003)

Keywords: glassy, amorphous, $\mathrm{Ni}-\mathrm{Nb}-\mathrm{Zr}$ alloy, mechanical property

\section{Introduction}

Rapidly solidified $\mathrm{Nb}-\mathrm{Ni}^{1)}$ and $\mathrm{Ni}-\mathrm{Zr}^{2,3)}$ alloys are known to have an amorphous phase in their wide composition ranges. Aoki et al. have examined hydrogen absorption properties of rapidly solidified $\mathrm{Ni}-\mathrm{Zr}$ alloys, in addition to the formation range of an amorphous phase. ${ }^{3)}$ It has also been reported that the amorphous $\mathrm{Ni}-\mathrm{Zr}$ alloys exhibit useful properties such as high efficient catalytic characteristics for hydrogenation of carbon monoxide ${ }^{4,5)}$ and hydrogenation of benzene, ${ }^{6)}$ and hydrogen permeable membrane. ${ }^{7)}$ Recently, Inoue et al. have found that Ni-based bulk glassy alloys with a large supercooled liquid region before crystallization are formed in the $\mathrm{Ni}-\mathrm{Nb}-\mathrm{Ti}-\mathrm{Zr}$ system. ${ }^{8)}$ It is well known that $\mathrm{Nb}$ and $\mathrm{Zr}$ metals exhibit high hydrogen permeability. ${ }^{9)}$ It is therefore expected that $\mathrm{Ni}-\mathrm{Nb}-\mathrm{Zr}$ alloys with glassy or amorphous phase are formed in a wide composition range by rapid solidification and exhibit high hydrogen permeability. In this paper we have investigated the formation ranges of glassy and amorphous phases in the rapidly solidified $\mathrm{Ni}-$ $\mathrm{Nb}-\mathrm{Zr}$ alloys and their thermal stability and mechanical properties.

\section{Experimental Procedure}

Ternary $\mathrm{Ni}-\mathrm{Nb}-\mathrm{Zr}$ alloy ingots were prepared by arc melting mixtures of pure $\mathrm{Ni}, \mathrm{Nb}$ and $\mathrm{Zr}$ metals with desired compositions in a purified argon atmosphere. Ribbons of about 20,25 and $40 \mu \mathrm{m}$ in thickness and about 1.5 and $50 \mathrm{~mm}$ in width were prepared by a single roller melt-spinning technique in an argon atmosphere. The structure of the meltspun ribbons was examined by $\mathrm{X}$-ray diffractometry $(\mathrm{Cu}-\mathrm{K} \alpha$, $35 \mathrm{kV}, 15 \mathrm{~mA}$ ). Thermal stability such as glass transition temperature $\left(T_{\mathrm{g}}\right)$, crystallization temperature $\left(T_{\mathrm{x}}\right)$, supercooled liquid region $\left(\Delta T_{\mathrm{x}}=T_{\mathrm{x}}-T_{\mathrm{g}}\right)$ and the crystallization process was examined by at a heating rate of $0.67 \mathrm{~K} / \mathrm{s}$ by differential scanning calorimetry (DSC). The tensile fracture strength was measured at a strain rate of $8 \times 10^{-4} \mathrm{~s}^{-1}$ with an Instron-type testing machine. The hardness was also measured by a Vickers microhardness tester with a load of $25 \mathrm{~g}$.

\section{Results}

We examined the formation tendency of an amorphous phase in rapidly solidified $\mathrm{Ni}-\mathrm{Nb}-\mathrm{Zr}$ alloys where $\mathrm{Zr}$ was added to the well-known amorphous $\mathrm{Ni}_{50} \mathrm{Nb}_{50}$ alloy. Figure 1 shows X-ray diffraction patterns of the rapidly solidified $\left(\mathrm{Ni}_{0.5} \mathrm{Nb}_{0.5}\right)_{100-x} \mathrm{Zr}_{x}(x=10,20,30$, and 40 at $\%)$ alloys. Only broad diffraction peaks are seen for all the alloys, indicating the formation of a single amorphous phase. It is recognized that the diffraction angle $(2 \theta)$ of the main broad peak shifts to a lower angle side with an increase of $\mathrm{Zr}$ concentration because of the larger atomic size of $\mathrm{Zr}$. Figure 2 shows the composition range in which amorphous $\mathrm{Ni}-\mathrm{Nb}-$ $\mathrm{Zr}$ alloys are formed by rapid solidification, together with the previous data of $\mathrm{Ni}-\mathrm{Zr}$ binary alloys. ${ }^{3)}$ The amorphous phase is formed in a wide composition range of 20 to 75 at $\% \mathrm{Ni}, 0$ to 60 at $\% \mathrm{Nb}$ and 0 to 80 at $\mathrm{Zr}$. Figure 3 shows differential scanning calorimetric (DSC) curves of the amorphous $\mathrm{Ni}_{60} \mathrm{Nb}_{40-x} \mathrm{Zr}_{x}(x=10,20$, and 30 at $\%)$ alloys. Here $T_{\mathrm{g}}$ and $T_{\mathrm{x}}$ denote the glass transition temperature and crystallization temperature, respectively. The DSC data indicate clearly that

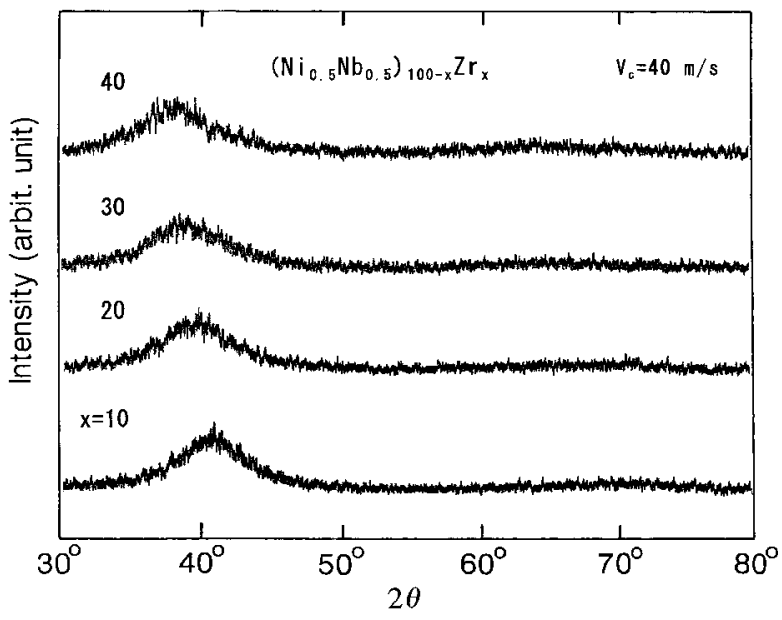

Fig. 1 X-ray diffraction patterns of rapidly solidified $\left(\mathrm{Ni}_{0.5} \mathrm{Nb}_{0.5}\right)_{100-x} \mathrm{Zr}_{x}$ $(x=10,20,30,40$ at $\%)$ alloys. 


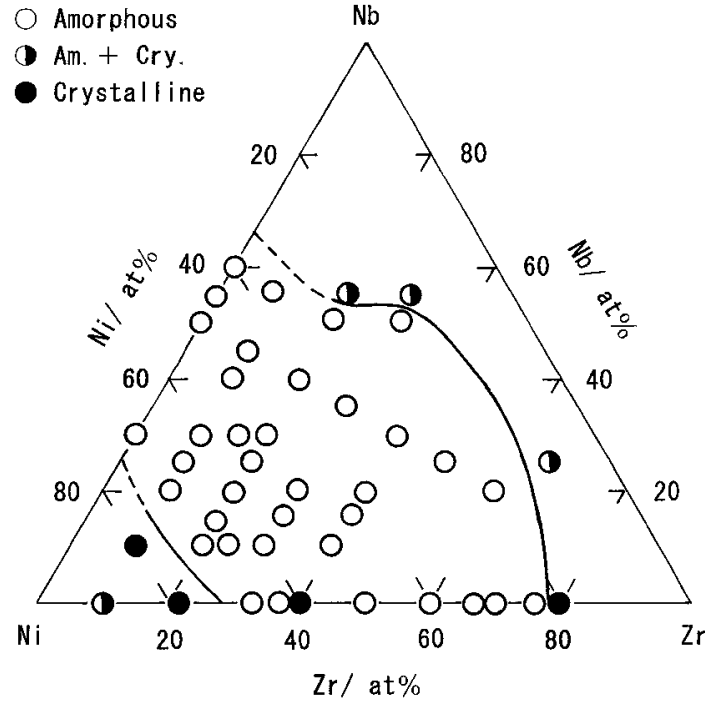

Fig. 2 Composition dependence of structure in rapidly solidified $\mathrm{Ni}-\mathrm{Nb}-$ Zr alloys.: $(\bigcirc)$ amorphous; $(\bigcirc)$ amorphous and crystalline; $(\bigcirc)$ crystalline. The single open circles represent the formation of amorphous alloys with good bending ductility.

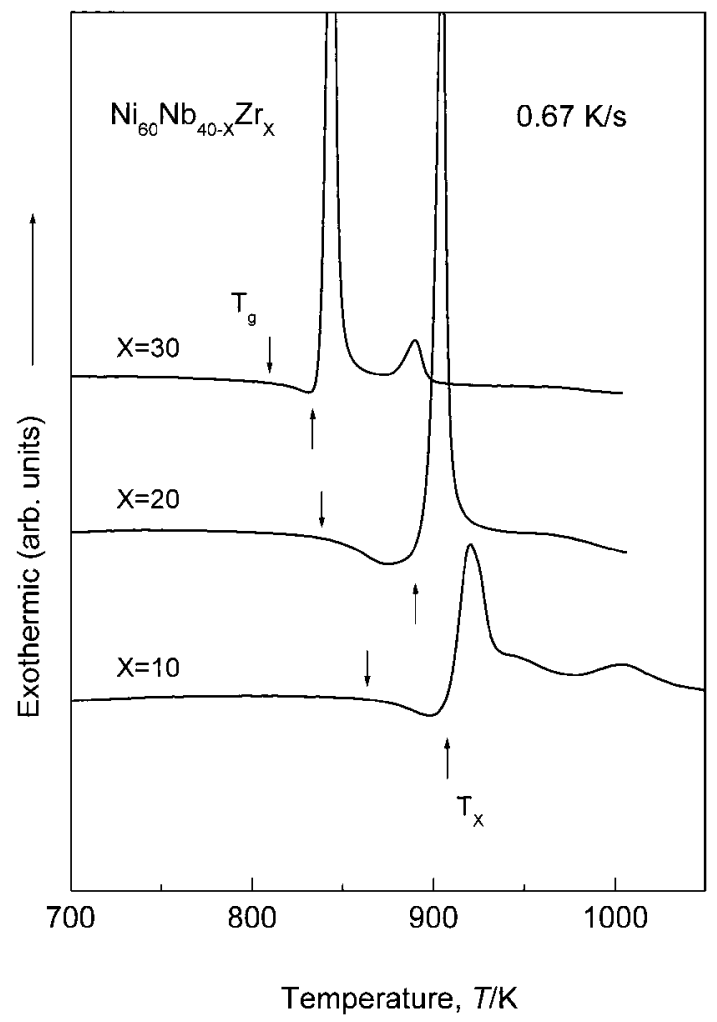

Fig. 3 Differential scanning calorimetric (DSC) curves of rapidly solidified $\mathrm{Ni}_{60} \mathrm{Nb}_{40-x} \mathrm{Zr}_{x}(x=10,20,30$ at\% $)$ alloys.

these Ni-based alloys have a glassy structure. The supercooled liquid region $\left(\Delta T_{\mathrm{x}}=T_{\mathrm{x}}-T_{\mathrm{g}}\right)$ is measured as $40 \mathrm{~K}$ at $x=10,51 \mathrm{~K}$ at $x=20$ and $24 \mathrm{~K}$ at $x=30$. Figure 4 summarizes the composition range of the glassy-type alloys. The glassy alloys are formed in the composition range of 50 to 70 at $\% \mathrm{Ni}, 5$ to $35 \mathrm{at} \% \mathrm{Nb}$ and 5 to 45 at $\% \mathrm{Zr}$. Figure 5 shows the composition dependence of $T_{\mathrm{x}}$ and $\Delta T_{\mathrm{x}}$ of the glassy $\mathrm{Ni}-\mathrm{Nb}-\mathrm{Zr}$ alloys. $T_{\mathrm{x}}$ and $\Delta T_{\mathrm{x}}$ are in the ranges from

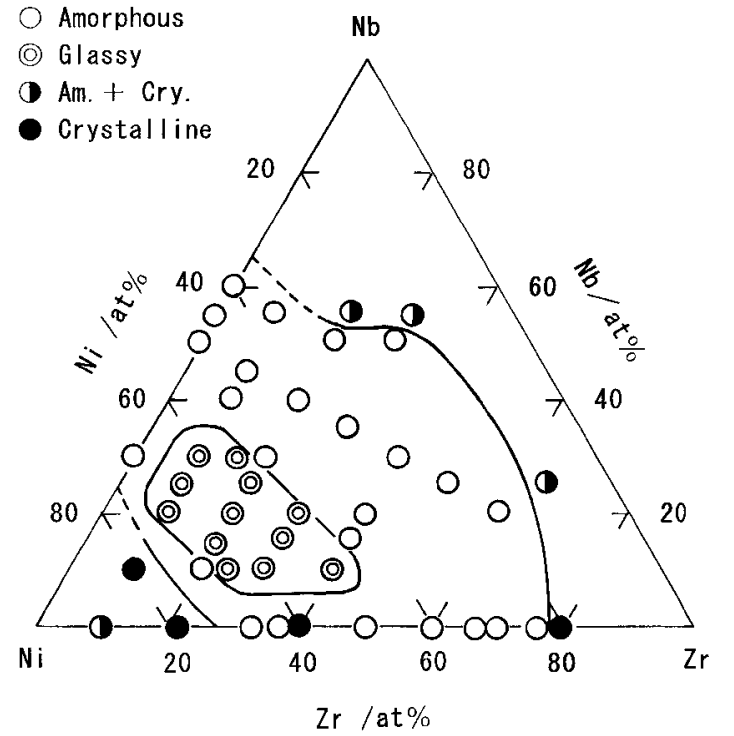

Fig. 4 Composition ranges of amorphous and glassy phases in rapidly solidified $\mathrm{Ni}-\mathrm{Nb}-\mathrm{Zr}$ alloys.: $(\bigcirc)$ amorphous; ( $($ ) glassy; ( $)$ amorphous and crystalline; $(\mathbf{O})$ crystalline. The double open circles represent the formation of glassy alloys.
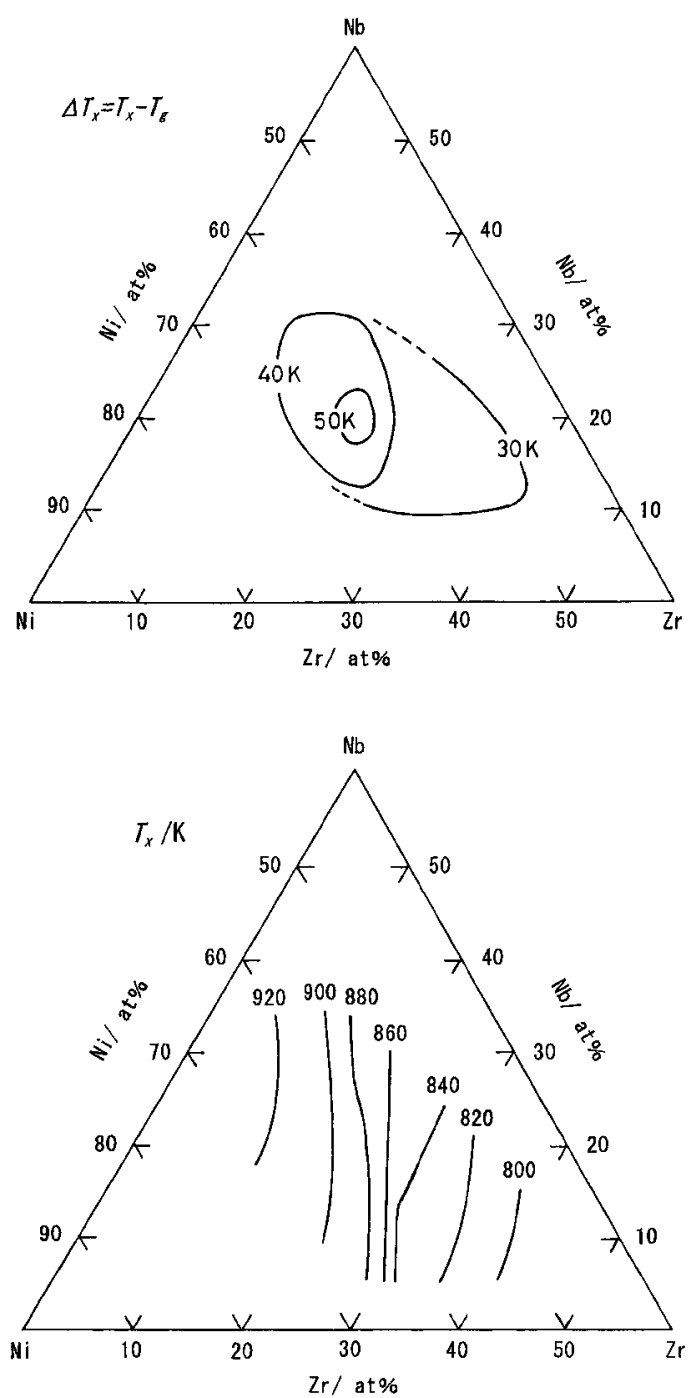

Fig. 5 Composition dependence of crystallization temperature $\left(T_{\mathrm{x}}\right)$ and supercooled liquid region $\Delta T_{\mathrm{x}}\left(=T_{\mathrm{x}}-T_{\mathrm{g}}\right)$ of glassy Ni-Nb-Zr alloys. 


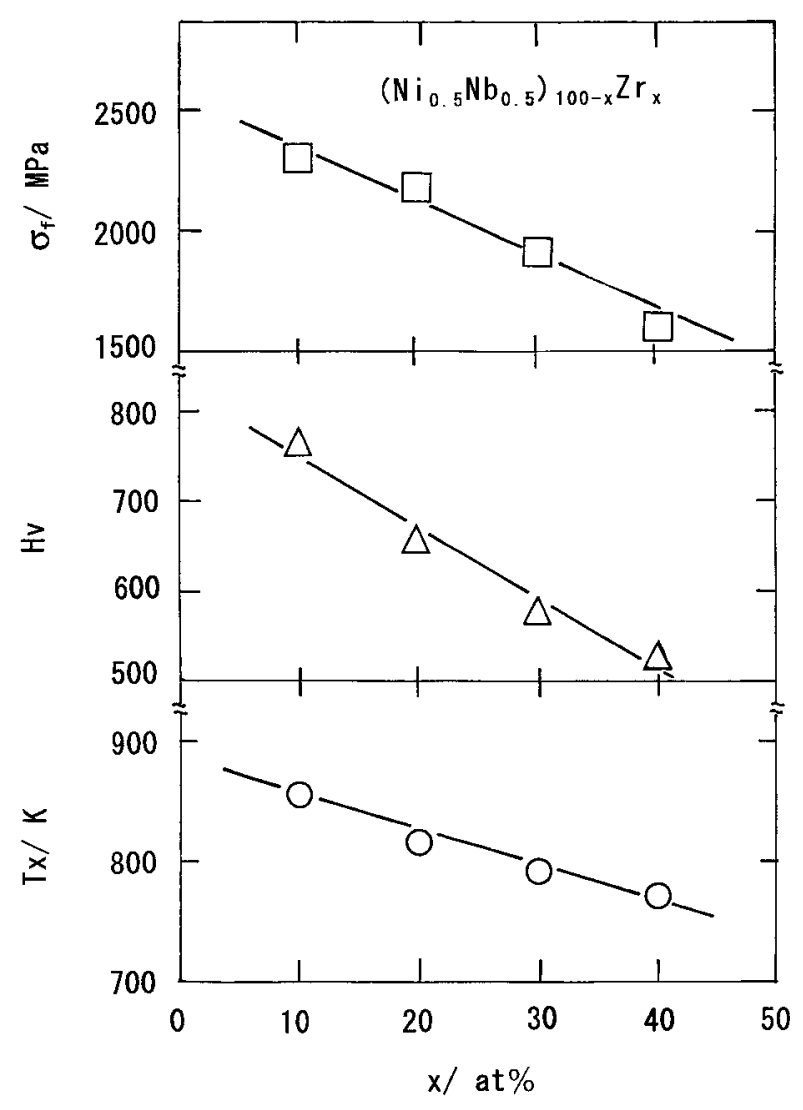

Fig. 6 Crystallization temperature $\left(T_{\mathrm{x}}\right)$, Vickers hardness $\left(H_{\mathrm{v}}\right)$ and fracture strength $\left(\sigma_{\mathrm{f}}\right)$ as a function of $\mathrm{Zr}$ content for amorphous $\left(\mathrm{Ni}_{0.5} \mathrm{Nb}_{0.5}\right)_{100-x} \mathrm{Zr}_{x}(x=10,20,30,40$ at $\%)$ alloys.

800 to $910 \mathrm{~K}$ and 20 to $55 \mathrm{~K}$, respectively. The highest $T_{\mathrm{x}}$ is $910 \mathrm{~K}$ for the $\mathrm{Ni}_{60} \mathrm{Nb}_{30} \mathrm{Zr}_{10}$ alloy while the largest $\Delta T_{\mathrm{x}}$ is $51 \mathrm{~K}$ for the $\mathrm{Ni}_{60} \mathrm{Nb}_{20} \mathrm{Zr}_{20}$ alloy. Figure 6 shows the crystallization temperature $\left(T_{\mathrm{x}}\right)$, Vickers hardness $\left(H_{\mathrm{v}}\right)$, and tensile fracture strength $\left(\sigma_{\mathrm{f}}\right)$ as a function of $\mathrm{Zr}$ content for the amorphous $\left(\mathrm{Ni}_{0.5} \mathrm{Nb}_{0.5}\right)_{100-x} \mathrm{Zr}_{x}(x=10,20,30$, and 40 at\%) alloys. The $T_{\mathrm{x}}, H_{\mathrm{v}}$ and $\sigma_{\mathrm{f}}$ increase almost linearly with decreasing $\mathrm{Zr}$ content and the highest values of $856 \mathrm{~K}$ for $T_{\mathrm{x}}$, 760 for $H_{\mathrm{v}}$ and $2300 \mathrm{MPa}$ for $\sigma_{\mathrm{f}}$ are obtained for the $10 \% \mathrm{Zr}$ containing alloy. Figure 7 shows the composition dependence of $H_{\mathrm{v}}$ and $\sigma_{\mathrm{f}}$ of the glassy $\mathrm{Ni}-\mathrm{Nb}-\mathrm{Zr}$ alloys. The $\sigma_{\mathrm{f}}$ is in the range from 1900 to $2400 \mathrm{MPa}$ and $H_{\mathrm{v}}$ lies in the range from 600 to 800 . There is a tendency for $H_{\mathrm{v}}$ and $\sigma_{\mathrm{f}}$ to increase with increasing $\mathrm{Nb}$ content. The highest values of $H_{\mathrm{v}}$ and $\sigma_{\mathrm{f}}$ are 760 for $\mathrm{Ni}_{60} \mathrm{Nb}_{30} \mathrm{Zr}_{10}$ and $\mathrm{Ni}_{50} \mathrm{Nb}_{20} \mathrm{Zr}_{30}$ alloys and $2340 \mathrm{MPa}$ for $\mathrm{Ni}_{60} \mathrm{Nb}_{30} \mathrm{Zr}_{10}$ alloy, respectively.

\section{Discussion}

Inoue et al. have produced a great number of bulk glassy alloys and found that the bulk glassy alloys have the following three component rules: ${ }^{10)}$ 1) multi-component system consisting of more than three elements, 2) significantly different atomic size ratios above about $12 \%$ among the main constituent elements, and 3) negative mixing enthalpy among their elements. Table 1 summarizes atomic size ratios ${ }^{11)}$ and mixing enthalpies ${ }^{12)}$ of the constituent elements in $\mathrm{Ni}-\mathrm{Nb}-\mathrm{Zr}$ system. The glassy $\mathrm{Ni}_{60} \mathrm{Nb}_{20} \mathrm{Zr}_{20}$ alloy exhibits the largest supercooled liquid region of $51 \mathrm{~K}$.
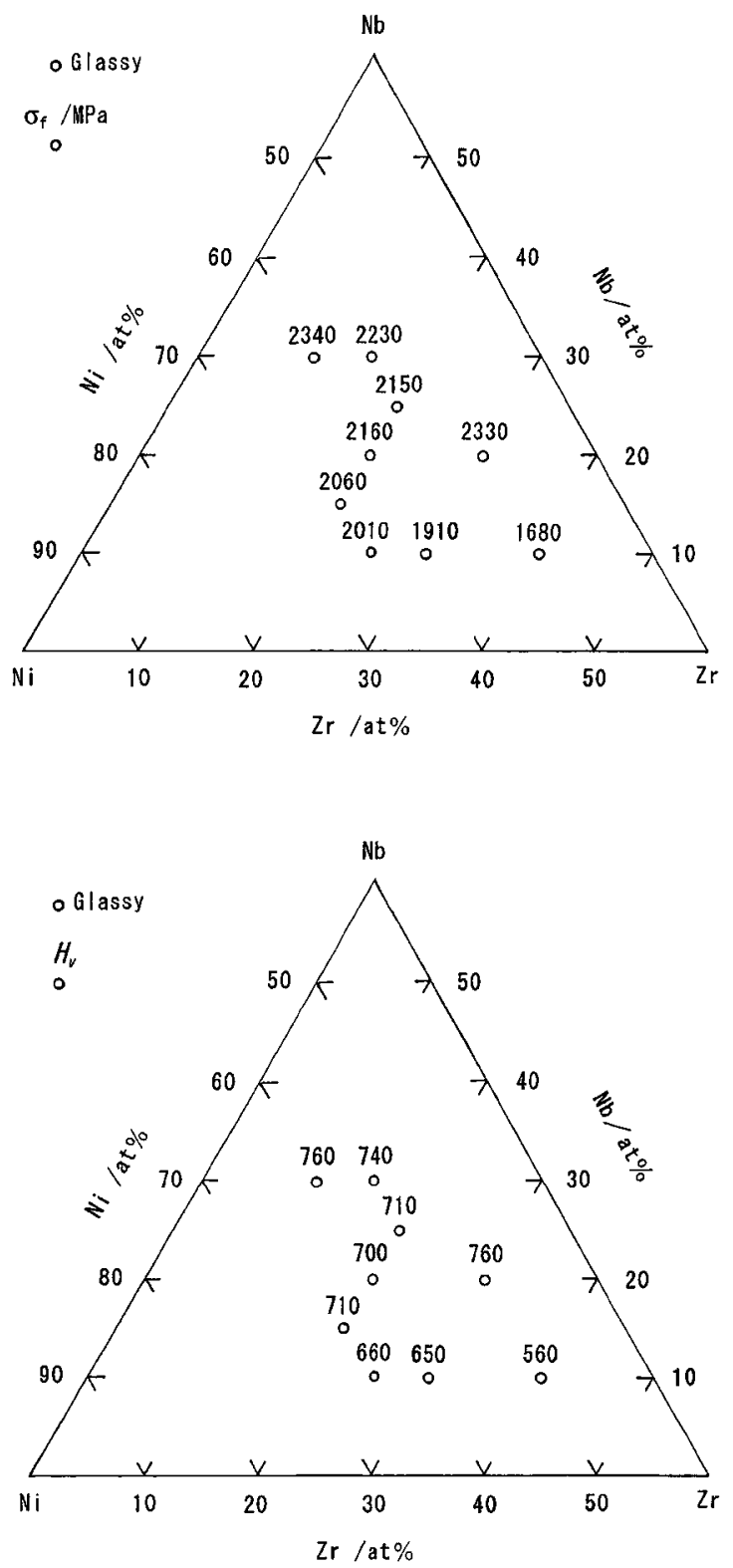

Fig. 7 Vickers hardness $\left(H_{\mathrm{v}}\right)$ and fracture strength $\left(\sigma_{\mathrm{f}}\right)$ of glassy $\mathrm{Ni}-\mathrm{Nb}-\mathrm{Zr}$ alloys.

Table 1 Atomic size ratios [small atomic radius $(r) /$ large atomic radius $(R)$ ] and mixing enthalpy $(\Delta H)$ among the constituent elements in $\mathrm{Ni}-\mathrm{Nb}-$ Zr system.

\begin{tabular}{ccc}
\hline Atomic pair & $\begin{array}{c}\text { Atomic size ratio } \\
r / R\end{array}$ & $\begin{array}{c}\text { Mixing enthalpy } \\
\Delta H / \mathrm{kJ} \cdot \mathrm{mol}^{-1}\end{array}$ \\
\hline $\mathrm{Ni}-\mathrm{Nb}$ & $0.87\left(r_{\mathrm{Ni}} / R_{\mathrm{Nb}}\right)$ & -30 \\
\hline $\mathrm{Ni}-\mathrm{Zr}$ & $0.77\left(r_{\mathrm{Ni}} / R_{\mathrm{Zr}}\right)$ & -49 \\
\hline $\mathrm{Nb}-\mathrm{Zr}$ & $0.88\left(r_{\mathrm{Nb}} / R_{\mathrm{Zr}}\right)$ & 4
\end{tabular}

Atomic radius, $\mathrm{Ni}: 0.125 \mathrm{~nm}, \mathrm{Nb}: 0.143 \mathrm{~nm}, \mathrm{Zr}: 0.162 \mathrm{~nm}$

As seen in Table 1, the above second rule is satisfied between the elements in the $\mathrm{Ni}-\mathrm{Nb}-\mathrm{Zr}$ alloys. On the other hand, mixing enthalpy between the pairs of $\mathrm{Ni}-\mathrm{Nb}$ and $\mathrm{Ni}-\mathrm{Zr}$ is negative, but that between $\mathrm{Nb}-\mathrm{Zr}$ is positive. Recently, Takeuchi and Inoue ${ }^{13)}$ have carried out the thermodynamical calculations of the mixing enthalpy for 6450 alloys in 351 ternary amorphous systems on the basis of the extended 


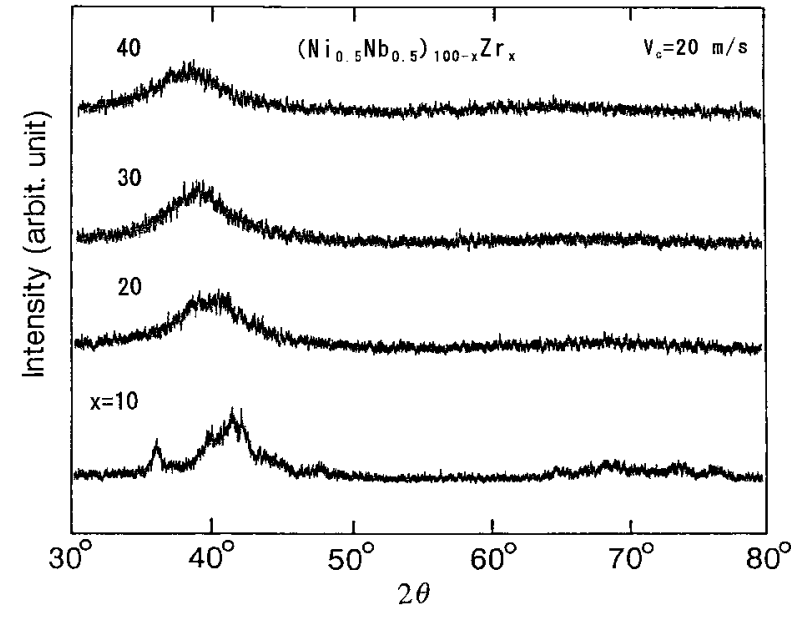

Fig. 8 X-ray diffraction patterns of rapidly solidified $\left(\mathrm{Ni}_{0.5} \mathrm{Nb}_{0.5}\right)_{100-x} \mathrm{Zr}_{x}$ $(x=10,20,30,40$ at $\%)$ alloys produced at a circumferential velocity of $20 \mathrm{~m} / \mathrm{s}$.

regular solution model. ${ }^{14)}$ Their results show that the chemical mixing enthalpies of most of them are able to be negative, even in the alloys in which mixing enthalpies between two pairs of constituent elements are negative and that between one pair is positive. According to their model, the chemical mixing enthalpy is estimated to be $-37.3 \mathrm{~kJ} \cdot \mathrm{mol}^{-1}$ for $\mathrm{Ni}_{60} \mathrm{Nb}_{20} \mathrm{Zr}_{20}$ alloy, supporting the above third rule.

When the glassy $\mathrm{Ni}-\mathrm{Nb}-\mathrm{Zr}$ alloys with high hydrogen permeability are used as a hydrogen permeable membrane, the glassy alloys must have a wide ribbon form. It is known that the wide ribbons can be prepared at lower cooling rate (low circumferential velocity of the copper roller) in a single roller melt-spinning technique. Figure 8 shows the $\mathrm{X}$-ray diffraction patterns of the melt-spun $\left(\mathrm{Ni}_{0.5} \mathrm{Nb}_{0.5}\right)_{100-x} \mathrm{Zr}_{x}$ alloy ribbons with a width of about $1.5 \mathrm{~mm}$ and a thickness of about $40 \mu \mathrm{m}$ which were prepared at the circumferential velocity of $20 \mathrm{~m} / \mathrm{s}$. When the $\mathrm{Zr}$ content exceeds 20 at $\%$, broad diffraction peaks due to an amorphous phase are seen. We further prepared amorphous $\mathrm{Ni}_{42} \mathrm{Nb}_{28} \mathrm{Zr}_{30}$ (a) and glassy $\mathrm{Ni}_{60} \mathrm{Nb}_{20} \mathrm{Zr}_{20}$ (b) alloy ribbons of $50 \mathrm{~mm}$ in width and $25 \mu \mathrm{m}$ in thickness as shown in Fig. 9. Figure 10 shows X-ray diffraction patterns of both the wide ribbons. It is seen that they have amorphous and glassy phases. The $50 \mathrm{~mm}$ for the ribbons is the maximum value which can be produced by using the present single roller equipment in our laboratory. The formation of wide amorphous and glassy alloy ribbons also indicates that the $\mathrm{Ni}-\mathrm{Nb}-\mathrm{Zr}$ alloys liquids have good cast ability in the melt-spinning process.

\section{Summary}

We examined the structure, thermal stability and mechanical properties of the rapidly solidified $\mathrm{Ni}-\mathrm{Nb}-\mathrm{Zr}$ alloys. The results obtained are summarized as follows:

(1) Amorphous alloys in $\mathrm{Ni}-\mathrm{Nb}-\mathrm{Zr}$ system were formed in a wide composition range of 20 to 75 at $\% \mathrm{Ni}, 0$ to 60 at $\% \mathrm{Nb}$ and 0 to 80 at $\% \mathrm{Zr}$.

(2) The $T_{\mathrm{x}}, H_{\mathrm{v}}$ and $\sigma_{\mathrm{f}}$ of the amorphous $\left(\mathrm{Ni}_{0.5} \mathrm{Nb}_{0.5}\right)_{100-x} \mathrm{Zr}_{x}(x=10,20,30$, and 40 at\% $)$ alloys are in the range from 770 to $870 \mathrm{~K}, 540$ to 760 and 1530

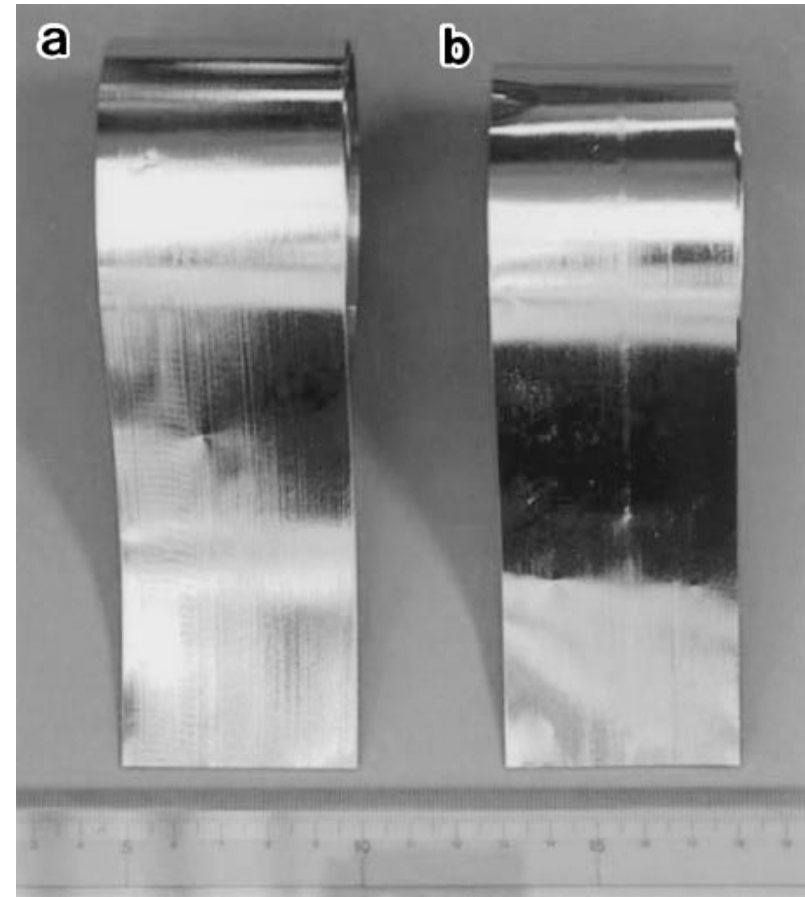

Fig. 9 Outer shape and surface morphology of amorphous $\mathrm{Ni}_{42} \mathrm{Nb}_{28} \mathrm{Zr}_{30}$ (a) and glassy $\mathrm{Ni}_{60} \mathrm{Nb}_{20} \mathrm{Zr}_{20}$ (b) alloy ribbons with a width of $50 \mathrm{~mm}$ and a thickness of $25 \mu \mathrm{m}$.

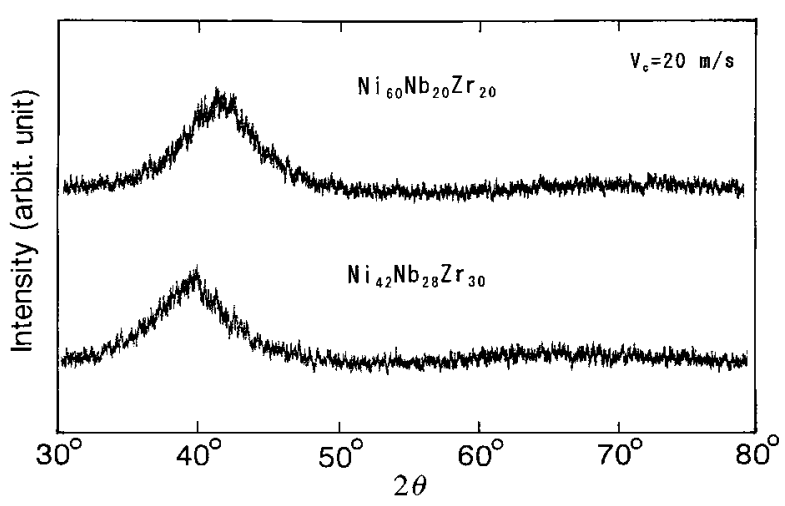

Fig. 10 X-ray diffraction patterns of amorphous $\mathrm{Ni}_{42} \mathrm{Nb}_{28} \mathrm{Zr}_{30}$ (a) and glassy $\mathrm{Ni}_{60} \mathrm{Nb}_{20} \mathrm{Zr}_{20}$ (b) alloy ribbons with a width of $50 \mathrm{~mm}$ and a thickness of about $25 \mu \mathrm{m}$.

to $2300 \mathrm{MPa}$, respectively. There is a tendency for $T_{\mathrm{x}}$, $H_{\mathrm{v}}$ and $\sigma_{\mathrm{f}}$ to increase with increasing $\mathrm{Nb}$ content.

(3) Glassy alloys in $\mathrm{Ni}-\mathrm{Nb}-\mathrm{Zr}$ system were also formed in the composition range of 50 to 70 at $\% \mathrm{Ni}, 5$ to $35 \mathrm{at} \% \mathrm{Nb}$ and 5 to 45 at $\% \mathrm{Zr}$. The largest value of the supercooled liquid region was $51 \mathrm{~K}$ for $\mathrm{Ni}_{60} \mathrm{Nb}_{20} \mathrm{Zr}_{20}$.

(4) The $\sigma_{\mathrm{f}}$ and $H_{\mathrm{v}}$ of the glassy $\mathrm{Ni}_{60} \mathrm{Nb}_{20} \mathrm{Zr}_{20}$ alloy with the largest supercooled liquid region are $2160 \mathrm{MPa}$ and 700 , respectively.

(5) Wide ribbons of $50 \mathrm{~mm}$ in width were prepared for the amorphous $\mathrm{Ni}_{42} \mathrm{Nb}_{28} \mathrm{Zr}_{30}$ and glassy $\mathrm{Ni}_{60} \mathrm{Nb}_{20} \mathrm{Zr}_{20}$ alloys at the circumferential velocity of $20 \mathrm{~m} / \mathrm{s}$. 


\section{Acknowledgements}

The authors wish to express their sincere thanks to Dr. A. Takeuchi, Institute for Materials Research, Tohoku University for his useful discussions.

\section{REFERENCES}

1) R. C. Rhul, B. C. Giessen, M. Cohen and N. J. Grant: Acta Mettall. 15 (1967) 1693.

2) K. H. J. Buschow and N. M. Beekmans: Phys. Rev. B 19 (1979) 3843.

3) K. Aoki, A. Horata and T. Masumoto: Proc. 4th Int. Conf. on Rapidly Quenched Metals (1981) 1649.

4) Y. Shimogaki, H. Komiyama, H. Inoue, T. Masumoto and H. Kimura: J. of Chem. Soc. Jap. 58 (1985) 661.

5) Y. Shimogaki, H. Komiyama, H. Inoue, T. Masumoto and H. Kimura: J. of Chem. Eng. Jap. 21 (1988) 293.
6) T. Takahashi, S. Higashi, T. Kai, H. Kimura and T. Masumoto: Catalysis Letters 26 (1994) 401.

7) S. Hara, K. Sasaki, N. Itoh, H. M. Kimura, K. Asami and A. Inoue: J. Membrane Sci. 164 (2000) 289.

8) A. Inoue, W. Zhang and T. Zhang: Mater. Trans. 43 (2002) 1952.

9) T. Seki and I. Yasuda: Distributed Energy Systems \& Fuel Cell Technologies, ed. by K. Hirata, (CMC Publishing Co., Ltd., Tokyo, 2001) p. 168.

10) A. Inoue: Mater. Trans., JIM 36 (1995) 866.

11) Metals Databook, ed. by Japan Inst. Metals, (Maruzen, Tokyo, 1984) p. 8.

12) F. R. Niessen: Cohesion in Metals, (Elsevier Science Publishers, B. V., Amsterdam, 1988).

13) A. Takeuchi and A. Inoue: Mater. Trans., JIM 41 (2000) 1372.

14) F. R. de Boer, R. Boom, W. C. M. Mattens, A. R. Miedema and A. K. Niessen: Cohesion in Metals (Cohesion and Structure, Vol. 1, ed. By F. R. de Boar and D. G. Pettifor), Elsevier Science Publishers B. V., Amsterdam, The Netherlands, (1988). 